\title{
The Role of Microfinance Institutions in Empowering Women in Eritrea
}

\author{
Dawit Teclemariam Bahta $^{1} \quad$ Jiang Yun $^{1} \quad$ Habteab Tekie $^{2} \quad$ Asmerom Atewebrhan $^{2}$ \\ Mehari Tewelde $^{2} \quad$ Henok Nugusse $^{2}$ \\ 1.School of Business Administration, Dongbei University of Finance and Economics, Dalian, China. \\ 2.College of Business and Social Science, Adi Keyih, Eritrea
}

\begin{abstract}
The purpose of this study was to examine the role of microfinance on women's empowerment. A comparative cross-sectional survey was conducted in Eritrea. This study used a quasi-experimental design that requires treatment and control groups. The data collected from a sample of 399 new and old women clients of the saving and microcredit program were used to analyze the role of microcredit services on women empowerment. Evidence from this study shows that participation in saving and microcredit programs (SMCP), increases the purchase of personal consumer goods, the degree of respect for women clients from their spouses, and next in kin and women's degree of social recognition. On the other side, the majority of participants asserted that decision-making ability in children's education, food expense, savings, business purchases, use of loans, and profits is shared with their spouses regularly. The findings of the study can help policymakers to design strategies that encourage more women to participate in microcredit programs to achieve their empowerment.
\end{abstract}

Keywords: Decision making, Microcredit, Saving, Women Empowerment

DOI: 10.7176/EJBM/11-36-09

Publication date: December $31^{\text {st }} 2019$

\section{Introduction}

Microfinance is an evolving socio-economic tool in the current competitive period that provides financial services on a small scale to low-income clients who lack access to banking and related services (Sarumathi and Mohan, 2011; Karlan and Goldberg, 2007). It has been used as an instrument in poverty reduction and women empowerment in developing countries since the establishment of the Grameen Bank in Bangladesh by Mohamed Younis in 1967. It is designed to provide low-income people pre-dominantly women opportunity to become selfsufficient by giving a means of borrowing and saving money. The services offered by microfinance institutions have been a popular intervention to fight poverty in developing countries, and it generally targets poor women (Leach and Sitaram, 2002). The purpose of loans provided by the microfinance institutions are mostly to empower women to have new initiatives to gain control over their destinies (Woodworth, 2000)

The World Bank has recently reported that countries which have gender-based discrimination have higher poverty, lower living standard, and weak economic growth. So the report has recommended that the empowerment of women should be used as a tool to ensure sustainable economic growth and development. This has complemented by Saravanan and DASH (2017) who asserted that women empowerment is key to the comprehensive growth of an economy. As a result, women empowerment in the development process has been one of the main concerns of almost all development strategies and programs, such as sustainable development goals. The number of women getting microcredit services has augmented rapidly after the fourth world conference on women in Beijing put women's access to credit on the international agenda in 1995.

The large proportion of microfinance beneficiaries are women, and its main objective is empowering them. Especially in developing countries, Microfinance institutions provide women financial support to start a business and to participate in the economy actively. This gives them confidence, increases their status and become more active in decision-making, which leads to gender equality.

With the achievements and contributions of the micro-credit institutions in Asia and in response to the international commitments in empowering women, Eritrea has enshrined female empowerment in its policies and development strategies as a means to improve the living standard of its people. The challenge in the case of Eritrea was not only the lack of collateral and financial records but also the small and underdeveloped financial institutions that were very limited in providing financial services. Thus in 1996, saving and microcredit Program (SMCP) was established to provide microfinance services to the population which the conventional financial institutions have failed to serve.

Like the majority of the microfinance programs, the main focus of SMCP is women and their empowerment and as one of its primary goals, strives to enhance the self- respect of women through different mechanisms such as social awareness, and proper use and repayments of loans on time. However, Microfinance as a vital tool in achieving women's empowerment, has been a controversial issue. On the one hand, it is argued that microcredit institutions have positive impacts on women's empowerment and households' well - being (Pitt et al., 2006; Steele et al., 1998; Pitt et al., 2003) On the other hand, it is contended that microfinance is thought to bring 
negative impacts for women (Hulme, 2000; Goetz and Sen Gupta, 1994; Rahman, 1999). Most studies in this area document the economic benefits of microfinance, only a few studies emphasis upon the benefits experienced by the women clients in isolation (Ajwani-Ramchandani, 2017) which implies, the need for more research to be done on the impact of microfinance in the empowerment of women. To the best knowledge of the researchers, no specific research has been done to investigate the role of saving and microcredit program institutions in achieving women empowerment in the case of Eritrea. Thus, this study aims to contribute to this literature by investigating the role of saving and microcredit programs on women empowerment in the context of Eritrea. The research question that guides the research is, does the saving and microcredit program institution contribute towards women empowerment in Eritrea?

\section{LITERATURE REVIEW}

The idea of women empowerment varies, as the behaviors and attributes that mean empowerment in one context differ from another context. Kabeer (1999) defined women empowerment as an expansion of people's ability to make strategic life choices in a situation where this ability was previously deprived of them. Microfinance as an essential tool in achieving the empowerment of women, has been controversial. Empirical studies reveal that the role of microfinance institutions to women empowerment share mixed results. While some are in favor of microfinance's ability in the process of economic, social and political empowerment, others are more doubtful and even point to the deterioration of women's general wellbeing (Holvoet, 2005; Meyer, 2002). Similarly, according to Hulme (2000), there are different arguments regarding the impact of credit on women. Some argue that microfinance has a positive influence on gender equality, women's empowerment, and households' wellbeing. Others argue that microcredit is thought to bring negative impacts for women

Concerning the positive effects of microfinance institutions on women, several studies show that access to microfinance contributes to women empowerment, including higher levels of mobility, welfare, political participation, and decision-making. For instance, according to Mayoux and Hartl (2009), microcredit program has been considered as contributing to social and economic empowerment, increased well-being and political empowerment for women, which addresses goals of gender equality and empowerment as it realized in Asian countries. Studies on microfinance and its impacts on women's empowerment in Ethiopia confirmed that microfinance interventions have positive implications in the improvement of economic status and empowerment of beneficiaries of the microfinance programs (Meron, 2007; Tsegaye, 2002). Weber and Ahmad (2014) in their study, found a positive association between increasing access to women finance by microfinance institutions (MFIs) and women empowerment in Pakistan. According to Mayoux (2001), MFIs, in general, have created a positive aspect for women empowerment through dominant three paradigms financial self-sustainability paradigm, poverty alleviation paradigm, and feminist empowerment paradigm. Kabeer (2005) examines the empirical evidence on the impact of microfinance concerning poverty reduction and poor women empowerment and finds that access to financial services leads to the women empowerment across South Asia.

Women's economic independence can also be increased by access to credit, which in turn can lead to improvement of women's status and self-worth in the households and the wider community (Goetz and Gupta, 1996; Kabeer, 2001). Similarly, Littlefield et al. (2003) reported that, since microfinance programs have generally targeted women as clients, access to it empowers women to have high confidence, high participation in family and community decision making, and have high ability to challenge systemic gender inequities. Another study by Gangadhar and Malyadri (2015) revealed that microcredit is an influential tool in improving women empowerment of women for its all indicators such as household decision making, physical mobility, economic security, and so on. Through loans microfinance institutions also empowers women and enable them for greater autonomy and decision-making. (Anderson and Eswaran, 2009).

Kabeer (2005) confirmed that microfinance has a positive effect on household decision making. Findings of a case study conducted in Ethiopia indicated that microfinance programs positively affect women's ability to participate in household decision-making fully. (Eshetu, 2007). The findings of Fofana et al. (2015) also reveals that the microcredit program increases women's decision-making power. Microcredit empowers women in numerous household decision-making and the household decision making power shifted from independently by the husband to jointly with wife and slightly by women themselves (Al-Shami et al., 2016). Sanyal in his study also found that women after attaining access to microcredit programs have the negotiating power in making several household decisions which include their physical mobility to their businesses and relatives (Sanyal, 2009). On the contrary to the above explanations, there are few studies on MFI and women empowerment that found little evidence for women's empowerment. A study in Ghana revealed varied results of the effect of access to microfinance, while some are empowered, but others have little control over the use of loans and are not better off; and are exposed to harassment and are worse off due to their incapability to repay loans on time (Ganle et al., 2015). A study conducted in Vietnam revealed that microfinance has no impact on borrower's income and expenditure (Nghiem et al., 2012).

Haile et al. (2012) contend that microfinance may lead to marital violence when men force their wives to 
take loans for their homes. The finding of Garikipati (2008) reveals that although giving a loan to women helps households to diversify livelihoods and reduce their vulnerability to shocks, but fails to empower women. Similarly, Duflo et al. (2013) in their study, found no effect of microfinance institutions on women's decisionmaking power. The literature review shows that, although the role of the microcredit programs in empowering women varies, it can be concluded that microfinance is a very effective instrument for the economic development in general and women empowerment in particular. This study intends to investigate the role of the saving and microcredit program in empowering women in the case of Eritrea.

\section{METHODOLOGY}

This study is a cross-sectional comparative study which is based on a saving and microcredit program (SMCP) field survey. The study examined the difference in outcomes on key variables between the target and control groups. The target group was defined as those beneficiaries who have been clients of the SMCP for more than two years. Whereas the control group was defined as the new clients who are in their first year as clients with $\mathrm{SMCP}$ and/or in their first loan cycle.

The sample has covered beneficiaries from five out of six administrative regions of Eritrea. A random sampling technique was utilized to recruit participants. A total of 399 women were included in this study. The 399 women were classified into target group $(n=331)$ and control group $(n=68)$. All participants were approached using a structured questionnaire. The questionnaire was adapted from previous studies and validated through a pilot study. Twenty women respondents were randomly designated to do the pilot study to test the quality of the questionnaire before its distribution.

IBM-SPSS software, V.21, was used for the statistical analysis. Descriptive statistics like percentages and frequency and chi-square were used to describe the socio-demographic characteristics and to assess women empowerment indicators. The percentage and frequency statistics are used to explore the demographic characteristics of the research participants. Whereas, chi-square is used to explore the differences in women empowerment among the categorical variables of demographic and women empowerment indicators.

\section{RESULT AND DISCUSSION}

4.1. Demographic characteristics of the respondents

Table 1: Demographic characteristics

\begin{tabular}{|c|c|c|c|c|c|c|c|}
\hline & \multicolumn{2}{|c|}{ Control Group } & \multicolumn{2}{|c|}{ Target Group } & \multicolumn{2}{|c|}{ Total } \\
\hline & & $\mathbf{N}$ & $\%$ & $\mathbf{N}$ & $\%$ & $\mathbf{N}$ & $\%$ \\
\hline \multirow{4}{*}{ Marital Status } & Married & 45 & $66 \%$ & 209 & $63 \%$ & 254 & $64 \%$ \\
\hline & Separated/divorced & 8 & $12 \%$ & 67 & $20 \%$ & 75 & $19 \%$ \\
\hline & Widowed & 12 & $18 \%$ & 49 & $15 \%$ & 61 & $15 \%$ \\
\hline & Single/never married & 3 & $4 \%$ & 6 & $2 \%$ & 9 & $2 \%$ \\
\hline \multirow{6}{*}{ Educational Level } & Illiterate & 39 & $57 \%$ & 131 & $40 \%$ & 170 & $43 \%$ \\
\hline & Informal & 9 & $13 \%$ & 27 & $8 \%$ & 36 & $9 \%$ \\
\hline & Elementary & 11 & $16 \%$ & 111 & $34 \%$ & 122 & $31 \%$ \\
\hline & Junior & 5 & $7 \%$ & 39 & $12 \%$ & 44 & $11 \%$ \\
\hline & Secondary & 3 & $4 \%$ & 18 & $5 \%$ & 21 & $5 \%$ \\
\hline & Above Secondary & 1 & $1 \%$ & 5 & $2 \%$ & 6 & $2 \%$ \\
\hline Total & & 68 & $100 \%$ & 331 & $100 \%$ & 399 & $100 \%$ \\
\hline
\end{tabular}

Table 1 shows, demographic characteristics of respondents. The majority of the sample respondents, 254 $(64 \%)$, were married. 75 (19\%) of the respondents were divorced whereas $61(15 \%)$ were widowed. Only $9(2$ $\%)$ were singles who had never married. Regarding the educational level, the majority of the respondents had no education or little education background, not exceeding the elementary level. The number of illiterate respondents was 170 (43\%). 36( $9 \%$ ) had an informal education with only reading and writing, about 122 (31 $\%)$ had the formal education that reaches up to the primary level and 44 ( $11 \%)$ had the formal education that reaches up to the junior level. The remaining 27 (7\%) had secondary level education and above.

\subsection{The Role of saving and microcredit program on decision making}

To examine the role of the saving and microcredit program on married women 's decision-making ability within the household, respondents were asked to indicate their decision making regarding domestic issues like children's education, food expenses, and savings, taking loans and uses and profit uses. Table 2 shows the decision-making ability of respondents. 
Table 2: Decision Making

\begin{tabular}{|c|c|c|c|c|c|c|c|c|c|c|c|c|}
\hline & Husband & & & & Husband a & Wife & & & Wife & & & \\
\hline Variables & $\begin{array}{l}\text { Control n } \\
(\%)\end{array}$ & $\begin{array}{ll}\begin{array}{l}\text { Target } \\
(\%)\end{array} \\
\end{array}$ & $\chi^{2}$ & $\mathbf{P}$ & $\begin{array}{l}\text { Control n } \\
(\%)\end{array}$ & $\begin{array}{ll}\text { Target } & n \\
(\%)\end{array}$ & $\chi^{2}$ & $\mathbf{P}$ & $\begin{array}{l}\text { Control n } \\
(\%)\end{array}$ & $\begin{array}{l}\text { Target } n \\
(\%)\end{array}$ & $\chi^{2}$ & $\mathbf{P}$ \\
\hline $\begin{array}{l}\text { Child } \\
\text { education }\end{array}$ & $10(22.2)$ & $37(17.7)$ & 0.501 & 0.479 & $17(37.8)$ & $82(39.2)$ & .033 & 0.856 & $15(33.3)$ & $79(37.8)$ & .317 & 0.574 \\
\hline $\begin{array}{l}\text { Food } \\
\text { expense }\end{array}$ & $11(24.4)$ & $26(12.4)$ & 4.287 & 0.038 & $16(35.6)$ & $79(37.8)$ & .080 & 0.778 & $16(35.6)$ & $95(45.5)$ & 1.475 & 0.225 \\
\hline Savings & $7(15.6)$ & $24(11.5)$ & .573 & 0.449 & $17(37.8)$ & $88(42.1)$ & .286 & 0.593 & $17(37.8)$ & $85(40.7)$ & .129 & 0.720 \\
\hline $\begin{array}{l}\text { Taking } \\
\text { loan }\end{array}$ & $6(13.3)$ & $19(9.1)$ & .751 & 0.386 & $21(46.7)$ & $89(42.6)$ & .251 & 0.616 & $16(35.6)$ & $92(44.0)$ & 1.085 & 0.298 \\
\hline Loan uses & $6(13.3)$ & $14(6.7)$ & 2.247 & 0.134 & $20(44.4)$ & $105(50.2)$ & .497 & 0.481 & $17(37.8)$ & $80(38.3)$ & .004 & 0.950 \\
\hline $\begin{array}{l}\text { Business } \\
\text { purchase }\end{array}$ & $5(11.1)$ & $32(15.3)$ & .525 & 0.469 & $21(46.7)$ & $82(39.2)$ & .848 & 0.357 & $16(35.6)$ & $81(38.8)$ & .161 & 0.689 \\
\hline Profit use & $3(6.67)$ & $18(8.6)$ & .185 & 0.667 & $23(51.1)$ & $99(47.4)$ & .208 & 0.649 & $16(35.6)$ & $79(37.8)$ & .080 & 0.778 \\
\hline
\end{tabular}

Decision Making on Children's Education: The majority of women in both groups claimed that they share decision making on their children's education together with their husbands. Although not statistically significant, more women from the target group stated that decisions on children's education are always or most of the time made by themselves.

Decision Making on Food Expenditure: The majority of women in both groups claimed that they decided on food expenditure by themselves. Although not statistically significant, more women from the target group stated that decisions on food expenses are always or most of the time made by their husbands.

Decision Making on Savings: The majority of women in both groups claimed that they share the decision on savings with their husbands. Although not statistically significant, more women from the target group stated that their husbands always make decisions on savings.

Decision Making on Taking Loans: The majority of women in the target group claimed that they decided on taking loans by themselves, whereas the majority of women in the control group claimed that they share the decision on taking loans with their husbands. However, there was no statistically significant difference between the two groups.

Decision Making on Loan Use: Though the decision on loan use was higher among the women in the target group compared with the control group, there was no statistically significant difference between the two groups.

Decisions on Business Purchases: The majority of women in both groups claimed that they share the decision on business purchases with their husbands. More women from the target group stated that decisions on loan use are always or most of the time made by themselves. However, there was no statistically significant difference between the two groups.

Decision on Profit Use: The majority of women in both groups claimed that they share the decision on how to use their profit together with their husbands. Although not statistically significant, more women from the target group stated that decisions on loan use are always or most of the time made by themselves.

The above evidence shows that in most cases, the majority of married women respondents from both groups share the decision making power on the above-raised matters equally with their husbands. Nevertheless, on the minority side, some women from the control group indicated that their husbands alone decide on these matters. In contrast, we observe some women from the target group claiming that they alone decide on these matters. However, it can be concluded that the majority of women in both the target and control groups feel that they are empowered at least to the extent of sharing decision making with their spouses.

4.3. The Role of saving and microcredit program on Purchase of Personal Consumer Goods Table 3: Purchase of personal consumer goods

\begin{tabular}{|l|c|c|c|c|c|}
\hline & Control Group & Target Group & Total & Chi-square & P-value \\
\cline { 2 - 4 } & $\mathbf{\%}$ & $\mathbf{\%}$ & $\mathbf{2}$ & \multirow{2}{*}{10.905} & \multirow{2}{*}{$0.001 *$} \\
\hline Yes & $29.5 \%$ & $52.8 \%$ & $48.7 \%$ & & \\
\hline No & $70.5 \%$ & $47.2 \%$ & $51.3 \%$ & & \\
\hline Total & $100.0 \%$ & $100.0 \%$ & $100.0 \%$ & & \\
\hline
\end{tabular}

*Significant at $5 \%$ level of significance

Purchasing of personal consumer goods is another indicator of women empowerment after continued participation in the saving and microcredit program. Table 3 shows the purchase of personal consumer goods of respondents. The majority $(70.5 \%)$ of women from the control group asserted that they did not purchase much of personal consumer goods such as clothing, cosmetics, jewelry, etc., for themselves in the recent past. On the other hand, the majority of women $(52.8 \%)$ from the target group have indicated that they purchased some consumer goods for themselves in the recent past. The difference between these two groups is found to be statistically significant at a $5 \%$ level of significance. The implication of this finding is that matured women 
clients are empowered in purchasing personal consumer goods than incoming clients.

4.4. The Role of saving and microcredit on Respect from Family members

Table 4: Respect from family members

\begin{tabular}{|l|c|c|c|c|c|}
\hline \multirow{2}{*}{} & Control Group & Target Group & Total & Chi-square & P-value \\
\cline { 2 - 4 } & $\mathbf{\%}$ & $\mathbf{\%}$ & $\mathbf{\%}$ & 5.661 & \multirow{2}{*}{$0.0295^{*}$} \\
\hline Little & $3.3 \%$ & $1.4 \%$ & $1.7 \%$ & & \\
Somewhat & $31.1 \%$ & $19.3 \%$ & $21.3 \%$ & & \\
\hline High & $65.6 \%$ & $79.3 \%$ & $77.0 \%$ & & \\
\hline Total & $100.0 \%$ & $100.0 \%$ & $100.0 \%$ & & \\
\hline
\end{tabular}

*Significant at $5 \%$ level of significance

Table 4 shows the respect respondents receive from family members. Compared to the control group, a higher proportion of the target group respondents indicated that they receive high respect from their husbands and other members of families. The result is statistically significant at $5 \%$ level of significance. This finding implies that women from the target group earn more respect from their husbands and family members than their counterparts in the control group. This shows that microfinance help women to increase their confidence and self-esteem.

\subsection{The Role of saving and microcredit on Degree of Social Recognition by Society}

Table 5: Degree of social recognition

\begin{tabular}{|c|c|c|c|c|c|}
\hline & Control Group & Target Group & Total & Chi-square & P-value \\
\hline & $\%$ & $\%$ & $\%$ & \multirow[t]{5}{*}{5.133} & \multirow[t]{5}{*}{$0.0385^{*}$} \\
\hline Little & - & $1.0 \%$ & $0.9 \%$ & & \\
\hline Somewhat & $36.7 \%$ & $23.3 \%$ & $25.6 \%$ & & \\
\hline High & $63.3 \%$ & $75.7 \%$ & $73.6 \%$ & & \\
\hline Total & $100.0 \%$ & $100.0 \%$ & $100.0 \%$ & & \\
\hline
\end{tabular}

*Significant at $5 \%$ level of significance.

Table 5 shows the degree of social recognition of respondents. Relative to the control group, a higher proportion of the target group respondents indicate that they got more respect and recognition from society. The result is statistically significant at 5\% level of significance. This finding implies that women from the target group earn more respect and recognition from neighbors than their counterparts.

\subsection{The Role of saving and microcredit on the degree of physical Mobility}

Table 6: Degree of physical mobility

\begin{tabular}{|l|c|c|c|c|c|}
\hline \multirow{2}{*}{ Q78 } & Control Group & Target Group & Total & Chi-square & P-value \\
\cline { 2 - 4 } & $\%$ & $\%$ & $\%$ & 3.252 & $1.77 * * *$ \\
\hline Never & $1.6 \%$ & $2.0 \%$ & $2.0 \%$ & & \\
Sometimes & $19.7 \%$ & $15.0 \%$ & $15.8 \%$ & & \\
Most of the times & $16.4 \%$ & $10.2 \%$ & $11.3 \%$ & & \\
\hline Freely and always & $62.3 \%$ & $72.8 \%$ & $71.0 \%$ & & \\
\hline Total & $100.0 \%$ & $100.0 \%$ & $100.0 \%$ & & \\
\hline
\end{tabular}

*** No significant difference between the two groups.

Table 6 shows the degree of physical mobility of respondents. The majority (71\%) of respondents claimed that they experienced a high degree of freedom to move from place to place, which implies that most of them do not face any restriction from their spouses or other family members to travel. However, there is no statistical difference between the two groups. This implies that better mobility may not necessarily be a direct result of participation in the saving and microcredit program, and it could be equally dependent on women's' individual household circumstances.

\subsection{Tension/Violence for being a Client of SMCP}

Table 7: Violence for being a Client of saving and microcredit program (SMCP)

\begin{tabular}{|c|c|c|c|}
\hline & Control Group & Target Group & Total \\
\cline { 2 - 4 } & $\mathbf{\%}$ & $\mathbf{\%}$ & $\mathbf{\%}$ \\
\hline Yes & $9.8 \%$ & $9.2 \%$ & $9.3 \%$ \\
\hline No & $90.2 \%$ & $90.8 \%$ & $90.7 \%$ \\
\hline Total & $100.0 \%$ & $100.0 \%$ & $100.0 \%$ \\
\hline
\end{tabular}

Table 7 shows the violence for being a client of SMCP. The majority (90.7\%) of women respondents declare that they never experienced any kind of violence, tension, or pressure from their husbands or next in kin 
for being clients of SMCP. The implication of these findings is that the majority of Eritrean society has a positive attitude towards saving and microcredit programs as a means of empowering women.

In general, from the above discussions, it can be determined that longtime client relationships of women with SMCP helped them to get empowered in the sense that it gave them more confidence and/or strength to do something to the benefit of themselves, their families and communities at large.

\section{Conclusion}

Microfinance program is considered a vital development policy to alleviate poverty and empowers women in many developing countries and Eritrea is not an exemption. Women are an influential force that can be empowered to the benefit of their families, society, and country to which they belong. Women can play a vital role in Eritrea's socioeconomic development if they are recognized as critical resources and given chances to participate. Access to credit is a crucial factor in empowering women and it typically takes the form of microfinance. Microfinance has become widespread in its potentiality to empower women who are significant customers of microfinance. The role of microcredit institutions to empower women is a controversial issue and different studies came up with varying results. This study examined the role of a microcredit program in empowering women in the Eritrean context. In Eritrea, the saving and microcredit program is appearing to be the leading microfinance institution serving people, particularly the poor and women. The findings of this study show that participation in SMCP assists women clients in getting empowered by giving them more confidence and strength to do something to the benefit of themselves, their families and communities at large. Evidence from this study shows that participation in SMCP increases the purchase of personal consumer goods, the degree of respect for women clients from their spouses and next in kin and women's degree of social recognition. On the other side, many women clients asserted that their decision-making ability on children's education, savings, business purchases, use of loans and profits is shared with their spouses regularly which implies that women are in the process of empowering themselves with regard to some aspects of decision making. Although extra efforts are required, the saving and microcredit program operating in Eritrea has been contributing positively towards women empowerment. It cannot be expected that microfinance programs that depend on only offering financial services to have a better impact on women's empowerment. Therefore microfinance institutions should also provide training, workshops on awareness creation for the success of women empowerment.

\section{References}

Ajwani-Ramchandani R (2017) The Role of Microfinance in Women's Empowerment: A Comparative Study of Rural \& Urban Groups in India. Emerald Publishing Limited.

Al-Shami SSA, Razali MM, Majid I, et al. (2016) The effect of microfinance on women's empowerment: Evidence from Malaysia. Asian Journal of Women's Studies 22(3): 318-337.

Anderson S and Eswaran M (2009) What determines female autonomy? Evidence from Bangladesh. Journal of Development Economics 90(2): 179-191.

Duflo E, Banerjee A, Glennerster R, et al. (2013) The miracle of microfinance? Evidence from a randomized evaluation. Reportno. Report Number|, Date. Place Published|: Institution|.

Eshetu H (2007) Impact of Micro-finance on women's economic Empowerment. A case-study of Amhara Credit and Saving Institution, Kobo Woreda, Amhara National Regional State Addis Ababa University, Ethiopia.

Fofana NB, Antonides G, Niehof A, et al. (2015) How microfinance empowers women in Côte d'Ivoire. Review of Economics of the Household 13(4): 1023-1041.

Gangadhar and Malyadri (2015) Impact of microfinance on women empowerment: An emperical evidence from Andhra Pradesh. Journal of Entrepreneurship \& Organization Management 4(2).

Ganle JK, Afriyie K and Segbefia AY (2015) Microcredit: Empowerment and disempowerment of rural women in Ghana. World development 66: 335-345.

Garikipati S (2008) The impact of lending to women on household vulnerability and women's empowerment: evidence from India. World development 36(12): 2620-2642.

Goetz AM and Gupta RS (1996) Who takes the credit? Gender, power, and control over loan use in rural credit programs in Bangladesh. World development 24(1): 45-63.

Goetz AM and Sen Gupta R (1994) Who takes the credit? Gender, power and control over loan use in rural credit programmes in Bangladesh.

Haile HB, Bock B and Folmer H (2012) Microfinance and female empowerment: Do institutions matter? Women's studies international forum. Elsevier, 256-265.

Holvoet N (2005) The impact of microfinance on decision-making agency: evidence from South India. Development and change 36(1): 75-102.

Hulme D (2000) Impact assessment methodologies for microfinance: theory, experience and better practice. World development 28(1): 79-98.

Kabeer N (1999) Resources, agency, achievements: Reflections on the measurement of women's empowerment. 
Development and change 30(3): 435-464.

Kabeer N (2001) Conflicts over credit: re-evaluating the empowerment potential of loans to women in rural Bangladesh. World development 29(1): 63-84.

Kabeer N (2005) Is microfinance a'magic bullet'for women's empowerment? Analysis of findings from South Asia. Economic and Political Weekly. 4709-4718.

Karlan DS and Goldberg N (2007) Impact evaluation for microfinance: Review of methodological issues. World Bank, Poverty Reduction and Economic Management, Thematic Group on Poverty Analysis, Monitoring and Impact Evaluation.

Leach F and Sitaram S (2002) Microfinance and women's empowerment: A lesson from India. Development in Practice 12(5): 575-588.

Littlefield E, Morduch J and Hashemi S (2003) Is microfinance an effective strategy to reach the Millennium Development Goals? Focus note 24(2003): 1-11.

Mayoux L (2001) Tackling the down side: Social capital, women's empowerment and micro-finance in Cameroon. Development and change 32(3): 435-464.

Mayoux L and Hartl M (2009) Gender and rural microfinance: Reaching and empowering women. International Fund For agricultural Development (IFAD), Powerguda: India.

Meron H (2007) The Role of Microfinance in Empowering Women in Addis Ababa. Unpublished Master's Thesis, Addis Ababa University, Ethiopia.

Meyer RL (2002) Track record of financial institutions in assisting the poor in Asia.

Nghiem S, Coelli T and Rao P (2012) Assessing the welfare effects of microfinance in Vietnam: Empirical results from a quasi-experimental survey. Journal of Development studies 48(5): 619-632.

Pitt MM, Khandker SR and Cartwright J (2006) Empowering women with micro finance: Evidence from Bangladesh. Economic Development and Cultural Change 54(4): 791-831.

Pitt MM, Khandker SR, Chowdhury OH, et al. (2003) Credit programs for the poor and the health status of children in rural Bangladesh. International Economic Review 44(1): 87-118.

Rahman A (1999) Micro-credit initiatives for equitable and sustainable development: who pays? World development 27(1): 67-82.

Sanyal P (2009) From credit to collective action: The role of microfinance in promoting women's social capital and normative influence. American Sociological Review 74(4): 529-550.

Saravanan S and DASH DP (2017) Microfinance and Women Empowerment-Empirical Evidence from the Indian States. Regional and Sectoral Economic Studies 17(2): 61-74.

Sarumathi S and Mohan K (2011) Role of Micro Finance in Women's Empowerment (An Empirical study in Pondicherry region rural SHG's). Journal of Management and Science 1(1): 1-10.

Steele F, Amin S and Naved RT (1998) The impact of an integrated micro-credit programme on women's empowerment and fertility behavior in rural Bangladesh.

Tsegaye T (2002) The impact of microfinance services among poor women in Ethiopia.

Weber O and Ahmad A (2014) Empowerment through microfinance: The relation between loan cycle and level of empowerment. World development 62: 75-87.

Woodworth WP (2000) Third world economic empowerment in the new millennium: Microenterprise, microentrepreneurship, and microfinance. SAM Advanced Management Journal 65(4): 19. 